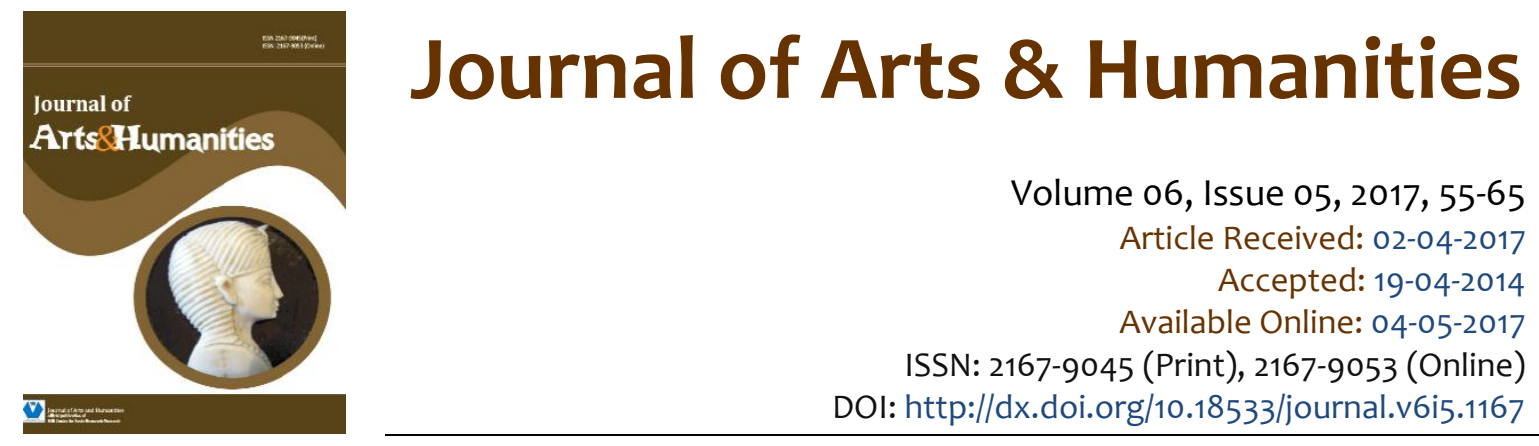

\title{
The origins of Muslim nationalism in British India
}

\author{
Enrique Baltar Rodriguez Ph.D. ${ }^{1}$
}

\begin{abstract}
British rule of India stripped Muslim elites of their traditional status of ruling class and reduced them to the status of a religious minority doubly pressured by the new conditions of colonial society and competition of the majority Hindu community. These pressures strengthened in the collective imagination the perception of a minority at a disadvantage and it helped the Muslim elites to become gradually aware of their right to constitute in nationhood and the need to organize politically to defend their interests. This article aims to analyze how Islamic nationalism was taking shape during the second half of the nineteenth century and an early twentieth century from two fundamental assumptions: the backwardness of the Muslim community and the fear of Hindu hegemony.
\end{abstract}

Keywords: Hindu, India, Muslim, Nationalism, XIX century.

This is an open access article under Creative Commons Attribution 4.0 License.

\section{Introduction}

In 1947 the British empire of India disappeared and from its ruins emerged two new independent states: the Indian Union and Pakistan. For the national movement led by the Indian National Congress (ICN), the independence gained meant an incomplete conquest, since the vision of a pan-Indian state was finally thwarted by the territorial partition. Meanwhile, for the Muslim League, the proclamation of Pakistan was the materialization of the so-called "two nations theory," an ideal that reflected the culmination of the process of ideological construction of Muslim nationalism in the Indian subcontinent.

The theory, enunciated by the poet and philosopher Muhammed Iqbal in 1930, considered Islam and Hinduism as two social orders with different and antagonistic cultural identities incapable of merging into a single nationality and living within the same state. Under that budget, Muslim identity became a pre-existing nation to claim its political recognition as a nation in its modern and western sense, and thereby justify the right to have a separate state.

\footnotetext{
${ }^{1}$ Senior Professor of the Political and International Studies Department, University of Quintana Roo. Vice-president of the
} Mexican Association of International Studies. 
Thus Islamic nationalism ended up adopting three basic arguments of nationalist doctrine: the idea of the will and aspiration of a pre-existing nation; the defense of the explicit and particular character of that nation; and the right to political sovereignty of the nation expressed in the existence of its own state (Smith, 1976: 47, 49). MA Jinnah made the third argument the main aspiration of the Muslim League in 1940, which came to fruition with the territorial partition of 1947, but the attainment of that state would not have been possible if the first two arguments had not already been firmly established in the social psychology of large sectors of the Muslim community.

The idea of a pre-existing Muslim nation and the defense of its explicit and particular character, began to conform during the second half of the nineteenth century to the heat of the transformations originated by British domination. The formation process of Muslim nationalism began in this historical context in counterpoint with the emergence of Hindu and Indian nationalism. This incipient nationalism was modern because it constituted the response of a part of the Muslim elites to the challenges posed by colonial domination and modernization; but its foundation was linked to a religious and cultural differentiation that, under those conditions, took on a new ideological and political meaning. In this article I analyze this initial period of the process with the intention of explaining why after several centuries of relative coexistence, at the end of the XIX century a Muslim nationalism began to form in British India from two fundamental presuppositions: the backwardness of the Muslim community and the fear of Hindu hegemony.

\section{Theoretical and methodological framework}

Nationalism presents a singular conceptual complexity as subject of study. Since the middle of the last century, its explanation has generated a wide variety of scientific literature, which could fall into three main categories: those that try to provide a general explanatory model of nationalism as a historical phenomenon and therefore have universalist pretensions; those that approach the phenomenon from a particular disciplinary perspective and focus on a specific field of expression (ideology, politics, economy, culture, education, etc.); and those referring to particular case studies that analyze the subject empirically or from some of the general theoretical perspectives. In this section I will briefly refer to the general explanatory models, then I will analyze the main approaches that have predominated in the study of Muslim nationalism in British India, especially in Pakistani and Indian historiography, and finally I will raise the central hypothesis that I intend to develop in this article.

In an attempt of simplification we could classify theories for the explanation of nationalism in two main primary branches. The fundamental question that determines this division is whether nationalism is understood as a fruit of modernity or, on the contrary, is considered a natural phenomenon. The central arguments of both positions developed widely between the 1960s and 1990s (Delannoi \& Taguieff, 1993), and retain their validity as classic references to nationalist theory. On each side, in turn, we find different theoretical currents that differ from each other in terms of the line of argument used.

Within the first branch we can locate the diffusionist current, represented by authors like Kohn (1955, 1961), Snyder (1964) and Kedouri (1960). For the first two nationalism had an Anglo-French origin, while the third puts the emphasis on the German matrix derived from Romanticism, but all coincide in explaining the general phenomenon from the ideological expansion of these nationalisms by the rest of Europe, first, and then to other regions through colonialism.

Another important group of currents in some way associates the emergence of nationalism with the process of modernization that led to the transition from traditional to industrial society. For the Nationbuilding school, headed by Rokkan (1973) and Deutsch $(1963,1969)$, the material aspects of modernization, particularly communications, played a decisive role as a basic premise for the mobility, integration and cohesion of societies. Authors like Smith (1976), on the other hand, explain the emergence of "polycentric" nationalism due to changes in the political superstructure and the imposition or attainment of what he called the "Scientific State" (modern) capable of exercising over population a dual effect, homogenizing and discriminatory. 
In another sense, the conflictivist theories seek the roots of nationalism in the tensions provoked by the erosion of the traditional order of roles and the inequalities represented by the new order of modernization. The changes, especially in culture and education, promoted the politicization of an uprooted intelligentsia (Gellner, 1991), contributed to awakening the national identity of ethnic groups that aspired to self-determination (Ronen 1979, Glazer \& Moynihan, 1975), or generated a political arena for the competition of elites (political, ethnic and religious) for the control of power or for the creation of their own state (Breuilly, 1990; Brass, 1991). The elites recreated the idea of national identity and turned nationalism into an effective instrument of political mobilization to defend the rights of a nation which, according to Anderson (1991), was in fact an imagined community.

The primordialist branch moves in a very different direction. These currents do not circumscribe nationalism to the modern period but consider it a natural phenomenon associated with ethnicity. For the precursors of the classical formulation as Shils (1965) and Geertz (1963), the primordial links, such as blood, race, language, region, religion, tradition and customs, have a fundamental explanatory value in the constitution of national identity and nationalism. This point of view was enriched by the contributions of Van den Berghe (1981), who introduced a sociobiological variant that explains the fundamental nature of ethnicity from an evolutionary view in which ethnic and racial feelings appear as an extension of feelings of kinship; and Gordon (1978) who argued that ethnicity not only had a sociobiological but also sociopsychological character, which contributes to the internalization of the sense of belonging and the differentiation between groups.

From my point of view, these general explanatory models of nationalism should not be taken as functional recipes to typify and classify the wide variety of nationalisms we find in past and recent history, especially when the spatial and cultural referent moves away from the western stage. Although almost all theories have universal pretensions, in fact they suffer in varying degrees from a remarkable Eurocentrism, prone to extrapolate scenarios and variables, or to underestimate, and even ignore, the particularities of the colonial and dependent periphery. Perhaps this original sin could be explained, at least in part, by the Anglo-Saxon and French origin of the authors who have set the standard in the elaboration of these theoretical constructions. Similarly, plot lines can give the impression of a relative bias by oversizing one aspect of the phenomenon to the detriment of others.

At the same time, they all offer valuable contributions to the study of nationalism. The importance and originality of many of the arguments put forward in these theories is undoubtedly evident. The reader will note that some of them have had a clear influence on my view of the problem, particularly those of Smith, Breuilly, and Brass. But in the analysis of nationalism - and this is at least demonstrated by the study of India - many factors of a diverse nature are synthesized, affecting all fields of social life (economic, political, ideological, cultural) and closely conditioned by the particular historical development of each region or territory. For these reasons, it seems so compromised to sacrifice the richness of a case study in order to validate a general theoretical construction, or to dismiss the explanatory contribution of the specific arguments that support each of these theories.

With regard to studies of Muslim nationalism and the origin of Pakistan, primordialist and instrumentalist lines of argument predominate. The first is based on the idea of intangibility between two social orders and presents the history of India, from the conquering irruption of Islam, as a period of permanent confrontation between two communities (Hindu and Muslim) who, despite ten centuries of historical coexistence, failed to interact to blur their rigid religious and cultural boundaries or, according to less severe opinions, the externality of that interaction never altered the particular essence of each. This approach was firmly established by Orientalist historiography, by some Indian historians such as Majumdar (1962), Panikkar (1971) and Ray (1973), and by a whole generation of Pakistani historians - such as Qureshi (1962), Malik (1963), Sayeed (1968), Aziz (1963) and Ikram (1965), among others - that laid the foundations for the country's official history. This approach continues to dominate Pakistani historiographical production: it is not surprising that Muslims have wanted to separate, what is incredible is that they have been able to coexist with Hindus for so many centuries (Adnan, 2006: 203). 
The second approach regards Islamic nationalism as construction and not the natural outcome of a primordial evolution (pre-existing nation). Indian nationalist historiography consistently attributes this construction to the combined centrifugal efforts of British colonialism and Muslim communalism to prevent the strengthening of Pan-Indian unity (see Chandra 1977: 8-25). On the other hand, authors like Brass (1991) and Breuilly (1990), consider it mainly a work of the elites, who found in the preexisting confessional feeling a source providing of symbols and an effective means for the political mobilization in favor of its own interests or their particular appreciation of the interests of the community.

The starting question of the present article points in the opposite direction to the primordialist interpretation: why differences that were latent by so many centuries came to crystallize in a new type of political identity at the end of the XIX? The hypothesis that I will try to demonstrate is that this was possible because those differences took on a new meaning in the political arena emerged from the colonial modernization. British domination did not play in India the regenerative mission that Karl Marx predicted in his articles of 1853. Modernization did not contribute to the establishment of a "Scientific State" in the sense coined by Smith (1976). On the contrary, the "Scientific State" was mimetized in colonial power and, as a result of that transfiguration, the efficiency and rational features of the former were distorted by the autocratic and discriminatory vocation of the latter. Moreover, the colonial state, instead of suppressing the religious foundations of the old social order, as one might suppose according to Smith's reasoning, gradually made them a fundamental component of the prevailing political system. In this context old identities were potentiated or new political and religious identities were constructed.

\section{The founding pillars of Muslim nationalism}

Unlike previous conquerors, the British invasion had a profound impact on the political, economic and social structures that underpinned the traditional ruling order in the Indian subcontinent. The effect was uneven at regional level and among various ethnic and religious groups, altering substantially the objective conditions of their relations and historical interests.

For the ruling class of the Muslim community the aftermath of the British irruption were visibly devastating. In the territories of the former Mughal Empire, the new conquerors wrested his political power and controlled the state apparatus. This alienation hurt severely not only his material interests, but also his pride as a ruling minority for more than ten centuries. The alleged Westernization of British politics in the first half of the nineteenth century, especially during the administrations of Lord Bentinck (1828-1835) and the Marquis Dalhousie (1848-1856), undermined so much the traditional bases of the dominant position of the Muslim elites (See Chhabra, 1985) On the one hand, the tendency to land expropriation significantly reduced the territorial basis of their economic power; and the other, the old attributes for access to the state administration (lineage, traditional education and Persian language) were replaced by new requirements culturally alien and socially "democratizing" (Western education, English language and proficiency tests,), because it could be acquired by any person or group, in particular by the elites of the majority Hindu community.

The restorer appearance of the failed Mutiny of 1857 made the British show implacable repression against Muslims, deepening the mutual distrust and plunged Muslims in a strong retreat in subsequent years. As a result, an own perception was formed about his place in British India which it marked the psychology of elites with a symbolic counterpoint, where nostalgia for a glorious past, embodied in the grandeur of the Mughal Empire, contrasted with his new sense of backwardness and fear of Hindu supremacy expressed in terms of demographics and greater degrees of participation in the main areas of colonial society.

Both perceptions, Muslim backwardness and Hindu threat, were inextricably linked and formed the diptych that would feed the future Islamic nationalism, but as a representation of reality presupposed a deliberate homogenization of communal situation. Paradoxically British colonialism contributed significantly to the implementation of this course in the collective imagination with the book The Indian 
Musalmans, written in 1871 by British civil servant WW Hunter (1876), who was charged with investigating the causes of Islamic hostility and growing popularity of Wahhabi movement that conducted a border war against the British in north Bengal until the seventies.

Because it was the conflict scenario and the center of British rule in India at that time, the investigation focused on the particular situation of Muslims in Bengal, but its findings were used to recreate in the circles of colonial power one stereotype of community that claimed the inferiority of aggrieved Muslim elites. In his report, Hunter categorically accepted the unequal effect exerted by Western education on the Muslim and Hindu communities (1876: 177); and, in general, he acknowledged that British rule had caused the decay of those who were before the conquerors and governors of the land (1876:151-152).

The theory of inequality implicit in the Hunter's book, laid the groundwork for a change in the relationship of British colonialism with the Muslim community in India, and made available to its elites an effective means to get concessions from the authorities. Until the Indian National Congress (INC), founded in 1885, came to give partial credit to this theory and academia became it the classic version of the explanation of Muslim separatism. ${ }^{2}$ However, in later decades, authors such as Paul Brass (1974; 1991), Francis Robinson (1974; 2001), Aparna Basu (1974) and Bimal Prasad (1999), among others, have consistently criticized this approach using statistics of that time.

Based on the Report of the Education Commission of India 1883, Prasad (1999) argues that Muslims access to education and government employment was uneven across regions and in relation to their demographic proportion. While in Bengal and the Punjab the Muslim population predominantly agrarian was really laggard in education and was underrepresented in modern professions and in the administrative bureaucracy, in Madras and Bombay the differences were less pronounced and in United Provinces, on the other hand, Muslim enjoyed a remarkable superiority.

Seen as a whole, the disadvantage even seemed oversized. Muslim population accounted $19.1 \%$ of the total in 1881 , while Muslim students enrolled in schools constituted $17.8 \%$. In 1886-87 they remained the same demographic weight, but the rate of enrolled students rose to $22.6 \%$. For the next thirty years the growth behaved proportionally. Toward 1931 Muslims accounted $24.7 \%$ of the population and $26.7 \%$ of the mass of students. However, this educational growth not reflected equally in all levels of education. In higher education particularly, Muslims held a share well below that of its demographic weight: only $3.65 \%$ of students in 1871 and $13.6 \%$ in 1931 (Prasad, 1999: 101-103).

On the other hand, the reality regarding government jobs did not seem so adverse as was noted in the Hunter report. In 1871, Muslims occupied $24 \%$ of the 372 senior officials aimed at natives in government service in all territories of British India, but that fact probably lost any practical meaning to the obvious sub-representation of Muslims in Bengal, where was the seat of colonial power. The main subject, however, was mostly a perspective problem. Unlike the previous powers, the colonial State introduced and expanded the field of public administration, becoming in a major employer and economic promoter. In that way, the proximity to government became a source of status and of socio-economic advancement and, therefore, in a principal scenario of competition and confrontation between political and religious elites (Khan, 2005). But what made this competition fiercer was the contradiction between the sustained growth of Western education and the limited availability of public office in the context of a backward and impoverished economy.

The colonial modernization, as symbiotic expression of the economic needs of British capitalism and its commitment to the traditional ruling elites (especially after the Mutiny of 1857), created a complicated network of economic relations with unequal development opportunities and articulated a deep structural dependency which erected in the main obstacle to modern progress (capitalist) of India. In

${ }^{2}$ This view of a uniform and backward Muslim community continues to maintain its argumentative force today (see Wassem, 2014). 
the words of noted historian Bipan Chandra (1979:4), the inability of native capitalism to industrialize the country was a product of the same process that gave birth colonial capitalism in India.

So, as Prasad says, the fundamental question not was in an objective inferiority of the Muslim community regarding to the Hindu in education and jobs, but in the fact that, according to their own interests, Muslim elites felt that it so was and its feeling grew up to the extent the competition became more ruthless (1999:106-108). That perception, increasingly entrenched in the collective imagination, helped to the Muslim elites were becoming aware of their right to constitute nationhood and the need to organize politically to defend their interests.

\section{Genesis and peculiarities of Muslim nationalism}

Paradoxically, the political initiative came not from the backward Muslim community of Bengal, but of powerful elites of United Provinces. ${ }^{3}$ According to Brass (1974: 178), this fact indicate that, in the creation of Muslim solidarity, the differences between Hindus and Muslims were less important that the objective process of symbol manipulation and construction of myths.

Muslims in the United Provinces were a strong and influential minority. The heart of the Mughal Empire had been in this territory and the elites came from a noble progeny and they had deeply rooted the Islamic ideal of a political and religious community, where power and religion were inextricably linked. ${ }^{4}$ For centuries they had controlled the senior government officials. In 1885 Muslims still accounted for only $13.4 \%$ of the total population of the region and occupied $45.1 \%$ of jobs for native in the executive and judicial apparatus of the provincial administration (Report of the Public Service Commission 18861887, 1888: 38; cfr. Prasad, 1999:107). The Muslim community was more urban than the Hindu; they accounted $50 \%$ or more of the population in twenty villages and between one half to one third in other thirty town. In general, Muslims contributed $38 \%$ of the urban population of the province. Its economic weight was also above their demographic proportion. A landowner class concentrated $20 \%$ of the land, especially in rural areas of Lucknow and Allahabad, two important centers of British power in the region. In industry and commerce, even they enjoyed a clear superiority over the Hindu community, due to the prevailing rural nature of the last one (Prasad, 1999: 109-110).

This strong position of Muslim elites in the social structure of the region helped to become United Provinces in the center of the two leading ideological trend of Indian Islam in the second half of the nineteenth century, symbolized by the Deoband Seminary and Aligarh College (Daly, 1982; Lelyveld, 1978). The Mutiny of 1857 marked a watershed in Islamic reform movements (Ahmad, 1984: 386). The new ideological streams were, above all, a regenerative response to the challenge imposed by culture and Western domination. From the point of religious and sociocultural view, the process took the form of a confrontation between traditionalists and modernists.

The first one adopted a Salafist character and pretended revitalize Islam by rescuing their original values. In general, they rejected the contributions of Western culture and assumed an anti-British attitude or, at least, avoided the collaboration with the colonial power. The main expression of this traditionalism was the Deoband Seminary (Deoband Dau-ul-Ulum), founded in 1867 by ulema Muhammad Qasim Nanantawi, veteran of Mutiny and famous polemicist of Christian missionaries and Hindu Arya Samaj movement's preachers. As educational institution, the Deoband was rigidly orthodox and sought to restore the influence of theologians in the educated middle classes of the Muslim community. His reputation grew immensely in the following years to transcend the borders of India and became the second school largest in the Islamic world after the Al-Azhar religious university in Cairo.

\footnotetext{
3 The name of United Provinces of Agra and Oudh appeared in 1902 when the British decided to integrate into a single administrative entity territories of North Western Provinces and Oudh province. The above 1902 statistical data used in this work are the result of the sum of the amounts corresponding to the two original provinces.

4 For Robinson $(2001,204-205)$ the influence of the Islamic ideal had a very important weight in political projection of Muslim elites of United Provinces. In his opinion, the weight of that argument lean the scale toward primordialist interpretation of Islamic nationalism and reveals the weakness of the instrumentalist approach Paul Brass.
} 
Modernists, for the contrary, promoted a change in attitude towards cultural values of British rule to prevent the definitive alienation of the Muslim community. Consequently, they began to promote Western education and sought colonial protection in exchange for loyalty to the Crown. The main expression of modernism was the Alligarh College, founded by Sayyid Ahmad Khan in 1875. Unlike Deoband, its role was provide Western education to Muslim elites for competing for government jobs and his educational philosophy, inspired mainly in the theory of inequality, supplied the ideological elements for Islamic nationalism germination.

Fears of Muslim backwardness and the threat of Hindu hegemony contributed to the creation of a political identity sponsored by some elites whose reality, apparently, did not correspond to that situation. Such paradox, however, is partly explained by several reasons. In principle, educational development of Muslims in the United Provinces vitiating of the same structural limitation. The participation of Muslims in education was globally important for its historical condition of supplier of high and medium bureaucracy, but still concentrated in traditional private schools, since their transfer to government education system proceeded more slowly. Approximately $43.7 \%$ of Muslim students attended to private schools for only $17.7 \%$ of Hindus in 1881 . Twenty years later the correlation was still $39.7 \%$ and $13.2 \%$, respectively (Robinson, 2001:167). With regard to modern primary and secondary schools, their percentage in enrollment was only proportional to its demographic weight in late 1860 and this proportion in higher education did not exist until almost three decades later. (Prasad, 1999: 111).

This allows to understand the importance of the educational project of Ahmad Khan and the important role he was called to play the Aligarh College in the political aspirations of Muslim elites. In Bengal, Madras and Bombay, where British rule had begun almost a century before, the Muslim disadvantage in Western education had led to bureaucratic rule of the higher castes of Hinduism. So signals setback in United Provinces fueled fears of Muslim elites about the political implications of the delay in modern education. For them, accustomed to their traditional dominance, the perception of lag was not seen in terms of demographic proportion, but in the degree of involvement of its historical interests. From 1881 to 1921 the proportion of Muslims in all United Provinces's government jobs increased from $34.8 \%$ to 47.7\%; however, with respect to high positions for natives in the executive and judiciary, its share fell from $63.9 \%$ in 1857 to $34.7 \%$ in 1913 . As Robinson says, compared to traditional employment expectations, the decline Muslim elites of United Provinces was noticeable during the second half of the nineteenth century (2001: 167).

Strengthening the Hindu communal identity did stronger the political impact of this shift. In a way, the formation of Islamic nationalism was a gradual reaction to the manifestation of a looming Hindu nationalism. The socio-religious movements, like the Arya Samaj led by Swami Dayanand Saraswati, and of the Vedanta of Swami Vivekananda, helped spread the superiority of Hinduism and claimed their autochthony, in contrast with the foreign and conqueror character of Islam. They also served as inspiration for cultural renewal and enhancement of vernacular languages through especially literature. Within that emotional environment, some symbols of cultural differentiation, as the administrative use of the Urdu language and the slaughter of cows, attributed to the past dominant role of Islam, acquired a new ideological background and became symbols of Hindu political activism in northern India and, in particular, United Provinces (See Brass, 1991: 75-86). Muslims of the region perceived its new environment in a different way. For them, the movement in favor of the Hindi language (Annesh, 2010) and against the slaughter of cows were signs of an emerging nationalism that aspired to Hindu supremacy and showed the religious oppression that Muslim minority could be exposed in a representative system (Brass, 1991: 79). The most finished form of this nationalism did not crystallize until 1915, when the All India Hindu Mahasabha was constituted precisely in United Provinces, but groupings with this trend had emerged in several places since the late nineteenth century, especially in the Punjab, where group Hindu Sabha achieved a remarkable expansion after 1882.

The appearance of the Indian National Congress (INC) in 1885, as expression of a new nationalist panIndian vision, reaffirmed the fears in some Muslim leaders about the threat of Hindu political 
hegemony. Sayyid Ahmad Khan, in particular, described the situation as "a civil war without weapons" (Cfr. Chhabra, 1984: 562) and assumed a sectarian position towards the Hindu-Muslim problem. Paradoxically, the Hindu origin of mostly its founders sowed suspicion that the democratizing claims by INC in favor of greater participation of Indians in the colonial government actually would result in greater benefits for the majority Hindu community.

Three additional factors contributed to reinforce this perception in the following years. One was the incorporation of some members to the INC from the ranks of Hindu nationalism who, as some Muslim politicians, interpreted the new vision of an Indian nation for its mainly Hindu character. ${ }^{5}$ Another had to do with the emergence of a radical wing within INC in the nineties-years that, as opposed to the liberal and conciliatory line of moderate leadership, drew on in different ways and in different degrees to the Hindu tradition to broaden the social base of nationalism (See Baltar, 2000). This gave rise, in the opinion of Bipan Chandra, to tragedy that over the years of training of Indian nationalism (1885-1919) the political nationalism was accompanied by social reaction and social reform by political conservatism (Chandra, 1979: 370).

The last factor was introduced by the colonial policy with handling of inter-confessional differences to prevent crystallization of a national self-consciousness pan-Indian. In 1906 Viceroy Lord Minto sealed the course of that strategy by supporting two cardinal requests for the strengthening of Islamic nationalism: the creation of separate electorates for Muslims and the right to political representation over their demographic proportion. "You claim rightly that their share is estimated, not only for its numerical strength, but in relation to the political importance of their community and the service they have rendered to the Empire. I completely agree with you" (Cfr. Mitchell, 1943:136).

Encouraged by viceroy's support, at the end of that year the Muslim League was founded with a still poorly defined program but with a clear pro-British orientation and a contrary inclination to INC. The introduction of separated electorates in 1909, stipulated by Morley-Minto Reforms, contributed to the forces polarization because independent confessional representation gave a political character to the Muslim League. Thanks to that, over time and British recognition, it became in a kind of official spokesman for the interests of the Islamic community and on an artificial counterpart of the INC. However, the pan-Islamist trend and the anti-British sentiments during First World War, as a result of British belligerence against Turkey, seat of the Caliphate and last Islamic power, modified for a while the political orientation of the Muslim League and created favorable conditions for a short interregnum of collaboration with INC and for reintegration of Indian Islam.

In 1916 INC and Muslim League signed Lucknow Pact, which by mutual agreement established the proportion of Muslim representation in each of the provincial assemblies and in the Central Legislative Assembly (Menon, 1979: 14-15). From 1919 to 1924 the Muslim League joined to Khilafat Conference, an organization that brought together Muslims most politically active in India in order to prevent the dismemberment of Turkey and preserve the integrity of the Caliphate, the spiritual home of Islam. The INC supported the cause of the Caliphate and acted in close coordination with the Khilafat movement, thanks to which it managed a wide participation of Muslims in the non-cooperation campaign organized by Gandhi in 1920 (Aziz Ahmad, 1984: 389).

With the triumph of Kemal Ataturk's nationalist movement, the proclamation of the Republic of Turkey and the abolition of the Caliphate in March 1924, the reason for the collaboration between the Muslim

\footnotetext{
${ }^{5}$ As a counterpart of that argument, it is worth mentioning the interest that the new pan-Indian vision of INC began to awaken in sectors of Muslim middle classes, a reality little recognized by Sayyid Ahmad Khan and his followers, but equally troubling. Of the 431 delegates at the second session of INC in1886, only 34 were Muslims; but in 1899 Muslims participation grew up to 300 of the 789 attendees at Lucknow session, a figure much more relevant for have taken place in a major center of United Provinces (Chhabra, 1984: 563).

${ }^{6}$ The petitions were submitted to the Viceroy by a delegation of Muslim notables headed by the Aga Khan III, an influential leader of the Ismaili sect, and Moshsim al-Mulk, Sayyid Ahmad Khan's successor as head of Aligarh movement (See Ahmad, 1984:389).
} 
League and the INC disappeared, and Indian Islam again divided politically. A sector continued to advocate for the pan-Islamist ideology, another maintained his loyalty to INC and in the strongholds of Muslim majority, politics even tended to regionalization and the predominance of local organizations with little motivation to act on the global stage. The Muslim League held its elitist character, but his projection pulled away definitely from the Indian nationalism and adopted the banner of "theory of two nations", which guided to Pakistan movement and conducted to territorial partition in 1947.

In the course of this road, however, the Muslim League had to abandon some of its original features to look for the ideological support of the ulama and to become a force capable of mobilizing large masses, especially farmers, in regions of Muslim majority that should form the territorial basis of future State (Baltar, 2012: 640-641). In that way, the modern heritage of the intellectual tradition of Alligarh College was forced to give ground to the symbolic attractive of a more traditional Islam.

\section{Conclusion}

The emerging Islamic nationalism of the late nineteenth and early twentieth centuries took several peculiarities that determined largely its further development. Geographically, its political center was in United Provinces where the Muslim community was a minority and their elites were being displaced from its dominant position, a situation that gave a very specific meaning to the danger of Hindu supremacy. Socially, it assumed an elitist and conservative character, especially intended for consumption of the educated middle classes, whose interests it really represented. It was also politically conservative, because their sense of vulnerability led him to seek protection under colonial arbitration and to oppose an increasing way to INC; and so to distance himself progressively of the perspective of a pan-Indian political movement. Ideologically, however, it adopted a secular and modern orientation, inspired by the tradition of Aligarh College and the political principles of Western culture.

These original traits had very important implications for the later development of Muslim nationalism and are indispensable antecedents for understanding key issues related to the formation and viability of the state of Pakistan. Until the 1930s, Islamic nationalism retained that modern and elitist foundational character, but the adoption of the two-nation theory presupposed a complex dilemma derived from the contradiction between its ideological foundations and its political viability. The justification of the separate state for the Muslim nation was inspired by the fear of Hindu hegemony, an idea which, as I have shown, emerged and flourished in places where Muslims constituted minorities. But the territorial base of that state could only come from the incorporation of the regions of Islamic majority where the Muslim League had little influence until that moment.

To achieve this incorporation, the Muslim League had to abandon some of its original features to look for the ideological support of the ulama and to become a force capable of mobilizing large masses, especially farmers, in regions of Muslim majority that should form the territorial basis of future State. In that way, the modern heritage of the intellectual tradition of Alligarh College was forced to give ground to the symbolic attractive of a more traditional Islam. Since then the Muslim League focused its attention on promoting the general idea of achieving a state for Muslims, but without specifying the character that state would have. Thus a clear definition of the Islam-State relationship remained pending, although for the religious imaginary that state could only have an Islamic nature.

In the 1940 s the Pakistani movement became increasingly popular thanks to religious (Islamic) mobilization and to the promise of broad autonomy for the regions that would form the new state, which could finally be founded on these bases. But when they came to power, the ruling elites pushed forward a project of secular and strongly centralist state. This change prepared the stage for the state, from then until now, would have to deal with the threats of the Islamist current and separatism ethnic groups. 


\section{References}

Abdul, M. (2006). Pakistan. Social and cultural transformations in a Muslim Nation. London and New York: Routledge, Taylos \& Francis Group.

Adnan, A. (2006). Pakistan: Creation and Genesis, In The Muslim World, 96(April), 201-217.

Ahmad, A. (1984). Islamic Reform Movements. In A Cultural History of India, (Ed. A. L. Basham), New Delhi: Oxford University Press.

Ahmed, F. (1998). Ethnicity and Politics in Pakistan. Pakistan: Oxford University Press.

Anderson, B. (1993). Imagined communities, London-New York: Verso.

Aneesh, A. (2010). Bloody Language: Clashes and Constructions of Linguistic Nationalism in India, In Sociological Forum, 5(1), 86-109. DOI:10.1111/J.1573-7861.2009.01158.x.

Aziz, K.K. (1967). The Making of Pakistan: A Study in Nationalism. London: Chatto \& Windus.

Baltar, E. (2000). India, reformismo, nacionalismo y partición. México: Universidad de Quintana Roo.

Basu, A. (1974). Education and Political Development in India, 1898-1920. New Delhi.

Brass, P. (1974). Language, Religion and Politics in North India. London: Cambridge.

Brass. P. (1991). Ethnicity and Nationalism. Theory and Comparison. New Delhi/Newbury Park/ London: Sage Publications.

Breuilly, J. (1990). Nacionalismo y Estado. Barcelona: Ediciones Pomares.

Chandra, B. (1979). Nationalism and Colonialism in Modern India. New Delhi: Orient Longman.

. (1977). Nuevas tendencias en la historia de la India. In Estudios de Asia y África, México, XII (1), 8-25.

Chhabra, G. S. (1985). Advanced Study in the History of Modern India (vol. 2, 1813-1919). New Delhi: Sterling Publishers Private Limited.

Daly Metcalf, B. (1982). Islamic Revival in British India: Deoband, 1860-1900. New Jersey: Princeton University Press.

Delannoi, G. \& Taguieff, P. (1993). Teorías del nacionalismo. Barcelona: Paidós.

Deutsch, K. (1969). Nationalism and Social Communication: An Inquiry into the Foundations of Nationality, M.I.I. Press.

Deutsch, K. \& Foltz, W. (1963). Nation Building, Michigan: Atherton Press.

Eaton, R. M. (c1993). The Rise of Islam and the Bengal Frontier, 1204-1760. Berkeley: University of California Press.

Geertz, C. (ed).(1963). Old Societies and New Studies, New York.

Gellner, E. (1991). Naciones y nacionalismo, México: Alianza Editorial.

Glazer, N. \& Moynihan, D. (1975). Ethnicity: Theory and Experiences. Cambridge: Harvard University Press.

Gordon, M. (1978). Human Nature, Class and Ethnicity. New York, Oxfod University Press.

Hunter, W. W. (1876). The Indian Musalmans. Third Edition, London: Trübner and Company, http://www.apnaorg.com.

Ikram, S. M. (1965). Modern Muslim India and the Birth of Pakistan, 1858-1951. Lahore.

Jalal, A. (1994). The Sole Spokesman. Jinnah, the Muslim League and the Demand for Pakistan. Cambridge: Cambirdge University Press.

Kedouri, E. (1960). Nationalism. Hutchinson University Library.

Khan, A. (2005). Politics of Identity. Ethnic Nationalism and the State in Pakistan. New Delhi-Thousand Oaks-London: Sage Publications.

Konh, H. (1955). Nationalism: its Meaning and History. Princeton: D.A. Nostrand Company. . (1961). The Idea of Nationalism: A Study in its Origin and Background. New Brunswick-London: Transaction Publishers.

Lelyveld, D. (1978). Aligarh's First Generation. New Jersey-Princeton: Princeton University Press.

Majumdar, R.C. (1962). History of the Freedom Movement in India. Calcutta.

Malik, H. (1963). Moslem Nationalism in India and Pakistan. Washington.

Menon, V. P. (1979). Transfer of Power in India. Nueva Delhi: Orient Longman.

Merchant, L. \& Sharif Al Mujahid (Ed.). (2009). The Jinnah Anthology. Karachi: Oxford University Press.

Mitchell, K. (1943). La India ante la guerra. Buenos Aires: Lozada. 
Pande, B.N. (1985). Concise History of the Indian National Congress 1885-1947. New Delhi: Vikas Publishing House.

Pániker, A. (2005). Índika. Una descolonización intelectual. Reflexiones sobre la historia, la etnología, la política y la religión en el Sur de Asia. Barcelona: Editorial Kairós,

Panikkar, K.M. (1971). A Survey of Indian History. London.

Prasad, B. (1999). The Foundations of Muslim Nationalism. New Delhi: Manohar.

Prasad, B. (2000). A Nation within a Nation 1877-1937. New Delhi: Manohar.

Ray, N. (1973). Nationalism in India. Aligarh: Aligarh Muslim University.

Robinson, F. (1974). Separatism among Indian Muslims: The Political of the United Provinces Muslims, 1860-1923. Cambridge: Cambridge University Press. . (2001). Islam and Muslim History in South Asia. London: Oxford University Press.

Rokkan, S. \& Eisenstadt, S.N. (1973). Building States and Nations. California: Sage.

Ronen, D. (1979). The Quest for Self-Determination. Yale University Press.

Sarkar, S. (1985). Modern India, 1885-1947. Madras: MacMillan India Limited.

Sayeed, K. B. (1968). Pakistan: The Formative Phase. London.

Shils, E. (1965). Political Devolopment in the New States. Mounton \& Co.

Smith, A. (1976). Las teorías del nacionalismo. Barcelona: Ediciones Península. . (1979). Nationalist Movements in the Twentieth Century. Oxford. (1981). The Ethnic Revival. Cambridge.

Snyder, L. (1964). The Dinamic of Nationalism: Reading in its Meaning and Development. Princeton: D.A. Nostrand Company.

Van den Berghe, P. (1981). The Ethnic Phenomenon. New York: Elsevier.

Waseem, F. (2014). Sir Sayyid Ahmad Khan and the Indentity Formation of Indian Muslim through Education, In Review of History and Political Science, 2 (2), 131-148. 